\title{
Elogio da lucidez. A comparação literária em âmbito universal; textos em homenagem a Tania Franco Carvalhal, de Eduardo F. Coutinho, Lisa Block de Behar y Sara Viola Rodrigues (comp.)
}

\author{
Reseña: Adriana Crolla
}

Evangraft, Porto Alegre, Brasil, 2004

Universidad Nacional del Litoral

Universidad Autónoma de Entre Ríos

"Tania Franco Carvalhal: elogio a la lucidez

en los senderos del comparatismo"

Los textos que integran el libro Elogio da lucidez. A comparação literária em âmbito universal, emprendimiento colectivo organizado por Eduardo F. Coutinho, Lisa Block de Behar y Sara Viola Rodrigues en homenaje a Tania Franco Carvalhal, constituyen por su variedad y riqueza, un valioso y actualizado aporte a las numerosas líneas de indagación que sobre los Estudios Comparados se diseñan actualmente en el mundo.

Publicado en el invierno del 2004 en Porto Alegre, Brasil, sus derechos de edición pertenecen al Instituto de Letras de la Universidad Federal de Río Grande do Sul donde la Dra. Carvalhal ha desarrollado su aquilatada y señera actividad profesional como docente y fundadora de los estudios comparados en Brasil.

Sus promotores explican en la nota introductoria el sentido del homenaje. Traduzco del portugués: "Reconociendo la importancia de Tania Franco Carvalhal dentro del ámbito de los estudios literarios, no sólo brasileño como internacionales, donde se destacó como docente, investigadora, crítica literaria, ensayista y gran emprendedora de debates y espacios de investigación, en particular en el ámbito de la Literatura Comparada, quisimos con este libro rendirle un homenaje en estos momentos en que cumple sesenta años de vida y cuarenta de intensas actividades profesionales."

El entusiasmo con que tantos intelectuales amigos respondieran a la convocatoria, engrosó notablemente la publicación dándole un perfil plural tanto de enfoques, como en lo genérico, temático, lingüístico y teórico. Pero como cuadra a toda iniciativa que transite las sendas del comparatismo, la unidad en la diversidad, la fluencia y el orden, son perfectamente alcanzados gracias a la forma de organización adoptada por sus responsables. El parentesco de ideas presentes en muchos de los trabajos, permitió por un lado la distribución temática agrupándolos primero por géneros y luego por asunto o tópico. Los ensayos, ámbito de especialización más transitado por la homenajeada, ocupa el espacio más amplio y evidente del libro y, por ende, fue dividido en ítems con títulos que indican claramente el tipo de indagación que los integran.

Como resultado de otra feliz elección de los compiladores, el espíritu comparatista que impera en el libro se demuestra en el respeto al origen y lengua en los que cada trabajo fue producido, lo que garantiza originalidad y transversalidad al tiempo que certifica el amplio radio de acción donde la Dra. Carvalhal ha operado su huella. El plurinlingüismo y multiculturalismo exige de los lectores apertura hacia las cuatro lenguas que lo integran, portugués, francés, inglés y español, y los diferentes ámbitos de producción de los cuales son emergentes y que, en su contacto, entretejen hilos de exquisita y densa configuración. 
El volumen cuenta con 51 colaboraciones agrupadas en tres bloques. La presentación de sus responsables y el texto "Uma joven talentosa" escrito en su honor por José E. Mindlin. Una segunda sección dedicada a Poesía y ficción integra 5 poemas y un cuento, escritos por sus autores, todos artistas de Brasil, en su homenaje. La tercera sección, dedicada al ensayo, consta de 7 partes bajo los siguientes títulos: 1. Literatura Comparada: teoria e crítica; 2. Literatura Comparada e outras artes; 3. Estudos de autores e obras; 4. Imagens do outro; 5 . O comparatismo e suas fronteiras; 6. O comparatismo na América Latina y 7. Depoimentos.

La brevedad y la densidad de aspectos involucrados en los trabajos, nos imposibilita abordarlos en su individualidad. Valga como referencia un intento de enunciación de su contenido a través de una somera enumeración de los problemas más recurrentemente abordados: Ética y estética de la comparación; perspectivas y abordajes teóricos actuales; la problemática del género y la traducción, literatura y cine, el documentalismo como forma de representación; la fotografía y el arte; estudios coloniales e imágenes de la alteridad (desde el análisis de la literatura de viaje a Tierra Santa pasando por la literatura portuguesa contemporánea hasta la recepción hispánica de la obra de Antonio Tabucchi). Los trabajos que integran la quinta sección indagan en el impacto de la globalización, del poscolonialismo y las nuevas formas de construcción del pensamiento en las liminalidades milenianistas. Las interrelaciones entre sistemas, géneros, literaturas y autores latinoamericanos, en particular del Brasil y sus hermanos hispanófonos, es ampliamente relevante, sin descuidar el análisis de itinerarios intertextuales como el dedicado al donjuanismo por parte del Dr. Pageaux. La última sección, la de los testimonios, tienen como objeto primordial el análisis de la intensa y variada actividad desarrollada por la Dra. Carvalhal y en particular destaco, su huella señera no sólo como embajadora del comparatismo brasileño en el mundo sino su gravitancia local como fundadora en 1985, de la Asociación Brasileña de Literatura Comparada, y desde ese ámbito, su innegable influencia en la gestación y desarrollo del comparatismo en la Argentina.

Valgan estas palabras como particular homenaje a quién tanto aportara para la generación y definición del perfil de la revista que dirigimos. Porque el Hilo de la fábula también es un retoño surgido por influjo de sus enseñanzas y la contó desde siempre como fructífero referente. La Dra. Tania Franco Carvalhal ha querido generosamente honorarla y prestigiarla, integrando su Comité Honorario. 